\title{
Virtual Classroom Instruction and Academic Performance of Educational Technology Students in Distance Education, Enugu State
}

\author{
Sylvester J. Akpan ${ }^{1}$, Paulinus J. Etim ${ }^{1, *}$ \& Udom, Stella Ogechi ${ }^{1}$ \\ ${ }^{1}$ Faculty of Education, University of Uyo, Uyo, Nigeria \\ *Correspondence: Faculty of Education, University of Uyo, Uyo, Nigeria. E-mail: Paulinusetim@yahoo.com
}

Received: September 29, 2016

Accepted: October 17, 2016 Online Published: December 15, 2016

doi:10.5430/wje.v6n6p83

URL: http://dx.doi.org/10.5430/wje.v6n6p83

\begin{abstract}
The virtual classroom and distance education have created new teaching pedagogy. This study was carried out to investigate Virtual Classroom Instruction on Academic Performance of Educational Technology Students in Distance Education, Enugu State. The population for this study was limited to the Students in National Open University, Enugu study Centre. Simple random sampling technique was used to select forty respondents from the educational technology students. A researcher developed questionnaire was used to gather the needed data. Collected data were analyzed using frequency counts and percentage. The findings from this paper suggested that the students' acknowledged that the availability and use of virtual classroom influenced their academic performance. Although the virtual classroom available was adequate, it was not often utilized for instruction. Thus, the researcher recommended that the virtual classroom should be utilized for maximum learning.
\end{abstract}

Keywords: virtual classroom, distance education, educational technology students; academic performance

\section{Introduction}

The classroom environment for teaching and learning has changed. A teacher is no longer needed to emphasize verbalism before a group of students, lecture and disseminate a list of questions to be answered for homework, and dismiss the class. Many schools are yearning to change the traditional brick-and-mortar classrooms with a physically present teacher and look on to technology driven strategies. In the online environment, students and teachers are virtually present. A virtual classroom is an online learning environment, created using internet, computers, sophisticated videoconferencing devices, in which either teacher is not physically present (for remote learning) or students are not present (distance education) at the same time in the classroom. Similarly, the virtual classroom is a tool for delivering live e-learning. It is often called "synchronous e-learning." The interface mimics the face-to-face classroom in many ways with a roster, hand-raising icon and an instructor leading the group. The primary difference between the face-to-face classroom training and virtual classroom training is that the latter is used to deliver content live, over the Internet to people who are geographically dispersed. Virtual classroom technologies (web-conferencing, video-conferencing, and tele-presence technologies)

The virtual classroom, generally, is appreciated by students as a result of the abundant resources and free time it allows as well as autonomous study, intuitive knowledge and selective contents (Falloon, 2012). Students must arrive on time, and when he/she enters into the classroom, he/she find a fixed classroom with teachers, fellow learners, a whiteboard, LCD projector, optionally a television screen with audio and video facility (Hall, 2012). Mallareddy (2013) investigated the use virtual classroom in Telugu Language teaching and noted that it was advantageous in removing the barriers of time and space, overcoming the unavailability of teachers; sessions can be recorded quicker to organize. However, there was lack of tools and technology, lack of interaction with learners. Gedera (2014) in an attempt to develop a better understanding of students' experiences of learning with the specific online learning technology of Adobe Connect virtual classroom discovered that students were satisfied with the platform of learning. Stating that in spite of the constraints of virtual classroom, most of the students preferred to have more virtual classroom activities because of the presence of cues and more human interactions.

The term distance education represents approaches that focus on opening access to education and training, freeing learners from the constraints of time and place. It offers flexible learning opportunities to individual and group 
learners. This is the most rapidly growing segment of education. The term distance education was given to the form of instruction that was available to the students by videoconferencing and interactive television in the mid-1980s. Currently, distance education is almost synonymous with the term virtual classroom. Though students prefer the asynchronous aspects of online education which gives them the flexibility in time and in space, very few studies have proved that asynchronous delivery is a better option than synchronous delivery (Cinar and Torenli, 2010).

With the increased popularity of the Internet, computer technologies are receiving more and more attention as a mean of delivering distance learning. The primary computer technologies used for distance learning include e-mail, online collaborations, and Web-based learning. The advantages of computer technologies are: they allow self-paced instruction, can incorporate text, graphics, audio and video, they allow high level of interactivity, provide written record of discussions and instruction, they are inexpensive and worldwide accessible.

The literature and studies related to distance education expanded considerably in the last years. Studies researched different aspects of distance education from its technologies, methods, and pedagogy to perceptions, opinions and attitudes of students and academicians toward distance learning. Perumalla, Mak, Kee and Mathews (2011) did a case study on the effectiveness of an online course and integration of web applications in order to improve the distance learning environment. Cinar and Torenli (2010) focused on redesigning the online courses in order to meet the expectations of enrolled students. Isik, Karakis and Guler (2010) examined postgraduate students' attitudes toward web based distance learning and revealed general positive attitude toward distance learning. Also, Karakoyun and Karak (2009) defined the opinion of academicians regarding distance learning. Beyth-Marom, Chajut, Roccas and Sagiv (2003) analyzed factors related to students' selection of Internet-assisted versus traditional distance learning. They discussed theoretical, methodological and practical implications. In all these, they reported the exertive influence of Distance Education on attitude of lecturers, students as well as enhancement of effectiveness of teaching, learning and students performance. In view of this, it becomes imperative to find out how availability and use of virtual classroom can influence educational technology students' academic performance in Open University, Enugu State-Nigeria.

Virtual classroom has been found to be very effective in the dispensation of Distance Education Programme in many countries of the world. The strategy has been extended as a veritable tool in enhancing teaching and learning in a diversified form of education. Unfortunately, the use of virtual classroom is seldom in Nigeria in many academic programs and only depends on potentialities established by many institutions. Only very recent that extension is given to adopting virtual classroom in teaching and testing of students in institutions and examination bodies.

The use of virtual classroom instruction increases in the educational and training domains, many people have recognized the importance of evaluating its effects on student outcomes such as learning, performance, and satisfaction but little or no effect is felt in Distance Education study center in Enugu state. This study investigated the availability and use of virtual classroom instruction and how it influenced educational technology students' performance in distance education in Enugu State Nigeria.

\section{Research Methods}

This study was conducted at the National Open University in Enugu State-Nigeria. The Study adopted the descriptive research design. Two research questions and one research hypothesis were formulated to direct the study. 40 out of 55 year three educational technology students were used to collect data for analysis. They were selected with the help of simple random sampling technique of the balloting system. The researcher-made instrument tagged "Use of Virtual Classroom and Academic Performance of Distance Education Students Questionnaire (UVCAPDESQ) was used for data collection. The instrument was validated by two academic experts in the department of Educational Technology department and Measurement and Evaluation unit of Educational Foundations Department all in the Faculty of Education, University of Uyo, Uyo-Nigeria. Their inputs were used to develop the final copy of the instrument used for data collection. Test retest method was used to collect information from 15 Educational Technology students of Distance Education in Enugu State center for reliability test. Their scores were treated to Cronbach Alpha statistics and yielded a reliability coefficient of .93. The instrument was adjudged reliable for use in the study. The data collected were analyzed using the descriptive statistics of the frequency counts simple percentages and t-test statistics. 


\section{Result and Discussion of Findings}

\subsection{Research Question One}

Does the availability of Virtual classroom facilities affect academic performance of Educational technology students in distance education?

In answering this research question, the research collated the respondents' responses to questionnaire items 1, 2, 3, 4, 5.6, 7 and 8 and the result is as presented in Table 1.

Table 1. Availability of Virtual Classroom Instruction Facilities

\begin{tabular}{lcccccccc}
\hline ITEMS & \multicolumn{7}{c}{ RESPONSES } \\
\hline Items & \multicolumn{2}{c}{ Adequate } & \multicolumn{2}{c}{ Inadequate } & \multicolumn{2}{c}{ Not available } & \multicolumn{2}{c}{ Total } \\
\cline { 2 - 9 } & $\mathrm{AF}$ & $\mathrm{RF}$ & $\mathrm{AF}$ & $\mathrm{RF}$ & $\mathrm{AF}$ & $\mathrm{RF}$ & $\mathrm{AF}$ & $\mathrm{RF}$ \\
\hline Live audio-video support & 18 & $40.0 \%$ & 11 & $27.5 \%$ & 11 & $27.5 \%$ & 40 & $100 \%$ \\
Session recording & 15 & $37.5 \%$ & 8 & $20.0 \%$ & 17 & $42.5 \%$ & 40 & $100 \%$ \\
Sharing screen or other material with & 15 & $37.5 \%$ & 6 & $15.0 \%$ & 19 & $47.5 \%$ & 40 & $100 \%$ \\
students & & & & & & & & \\
White board & 29 & $72.5 \%$ & 4 & $10.0 \%$ & 7 & $17.5 \%$ & 40 & $100 \%$ \\
Option to raise hand for asking query & 28 & $70.0 \%$ & 7 & $17.5 \%$ & 5 & $12.5 \%$ & 40 & $100 \%$ \\
Multi-level fallback mechanism & 19 & $47.5 \%$ & 15 & $37.5 \%$ & 6 & $15.0 \%$ & 40 & $100 \%$ \\
Live tech support & 23 & $57.5 \%$ & 11 & $27.5 \%$ & 6 & $15.0 \%$ & 40 & $100 \%$ \\
Synchronous learning & 21 & $52.5 \%$ & 15 & $37.5 \%$ & 4 & $10.0 \%$ & 40 & $100 \%$ \\
\hline
\end{tabular}

*AF=Absolute Frequency, $\mathbf{R F}=$ Relative Frequency $(\%)$

From the result obtained, it indicated that $40.0 \%$ of the respondents were of the opinion that live audio-video support was adequate, $27.5 \%$ opined that it was inadequate while $27.5 \%$ respondents said it was not available. Similarly, $37.5 \%$ of the respondents were of the opinion that session recording was adequate, $20.0 \%$ of the respondents were of the opinion that session recording was inadequate while $42.5 \%$ of the respondents were of the opinion that session recording was not available. However, $47.5 \%$ opined that multi-level feedback mechanism was available, $37.5 \%$ of the respondents opined that they were inadequate while $15.0 \%$ opined that they were not available. Thus, there is multi-level feedback mechanism in the virtual classroom. This result implies the availability of some virtual classroom facilities

\subsection{Research Question 2}

Does the use of Virtual classroom affect academic performance of Educational technology students in distance education?

The result of the analysis is as seen in table 2

Table 2. Utilization of virtual classroom for instruction

\begin{tabular}{lcccccccccc}
\hline \multicolumn{1}{c}{ ITEMS } & \multicolumn{10}{c}{ RESPONSES } \\
\hline \multicolumn{1}{c}{ Survey Item or Question } & \multicolumn{2}{c}{$\begin{array}{c}\text { Very Often } \\
\text { Utilized }\end{array}$} & \multicolumn{2}{c}{$\begin{array}{c}\text { Often } \\
\text { Utilized }\end{array}$} & \multicolumn{2}{c}{$\begin{array}{c}\text { Not Often } \\
\text { Utilized }\end{array}$} & \multicolumn{2}{c}{$\begin{array}{c}\text { Never Often } \\
\text { Utilized }\end{array}$} & \multicolumn{2}{c}{ Total } \\
& AF & RF & AF & RF & AF & RF & AF & RF & AF & RF \\
\hline Live audio-video support & 4 & $10.0 \%$ & 6 & $15.0 \%$ & 21 & $52.5 \%$ & 9 & $22.5 \%$ & 40 & $100 \%$ \\
Session recording & 6 & $15.0 \%$ & 7 & $17.5 \%$ & 16 & $40.0 \%$ & 11 & $27.5 \%$ & 40 & $100 \%$ \\
Sharing screen or other material with & 8 & $20.0 \%$ & 5 & $12.5 \%$ & 19 & $47.5 \%$ & 8 & $20.0 \%$ & 40 & $100 \%$ \\
students & & & & & & & & & & \\
White board & 9 & $22.5 \%$ & 6 & $15.0 \%$ & 20 & $50.0 \%$ & 5 & $12.5 \%$ & 40 & $100 \%$ \\
Option to raise hand for asking query & 7 & $17.5 \%$ & 5 & $12.5 \%$ & 24 & $60.0 \%$ & 4 & $10.0 \%$ & 40 & $100 \%$ \\
Multi-level fallback mechanism & 6 & $15.0 \%$ & 4 & $10.0 \%$ & 26 & $65.0 \%$ & 4 & $10.0 \%$ & 40 & $100 \%$ \\
Live tech support & 6 & $15.0 \%$ & 8 & $20.0 \%$ & 21 & $52.5 \%$ & 5 & $12.5 \%$ & 40 & $100 \%$ \\
Synchronous learning & 6 & $15.0 \%$ & 6 & $15.0 \%$ & 23 & $57.5 \%$ & 5 & $12.5 \%$ & 40 & $100 \%$ \\
\hline
\end{tabular}

$* \mathrm{AF}=$ Absolute Frequency, RF =Relative Frequency (\%) 
The results on table 2 indicates that $10.0 \%$ of the respondents use live audio-video support very often, $15.0 \%$ use it often, $52.5 \%$ not often while $22.5 \%$ never used it. Also, $15.0 \%$ of the respondents were of the opinion that session recording was very often used, $17.5 \%$ often used, $40.0 \%$ not often used while $27.5 \%$ never used. Again $60.0 \%$ of the respondent did not often use Multi-level fallback mechanism. 52.5\% did not use live technology support often and 57.5\% of the respondents did not use synchronous learning often. This implies that virtual classroom was not sufficiently used in teaching and learning during Distance Education programme.

Table 3. Influence of Use of Virtual Classroom Instruction on Student Academic Performance of Distance Education Students

\begin{tabular}{|c|c|c|c|c|c|c|c|c|c|c|}
\hline \multirow[t]{2}{*}{ Survey Item or Question } & \multicolumn{2}{|c|}{ SA } & \multicolumn{2}{|c|}{$\mathbf{A}$} & \multicolumn{2}{|c|}{ D } & \multicolumn{2}{|c|}{ SD } & \multicolumn{2}{|c|}{ Total } \\
\hline & $\mathrm{AF}$ & $\mathrm{RF}$ & $\mathrm{AF}$ & RF & $\mathrm{AF}$ & $\mathrm{RF}$ & $\mathrm{AF}$ & $\mathrm{RF}$ & $\mathrm{AF}$ & RF \\
\hline $\begin{array}{l}\text { Virtual Classroom provide flexible } \\
\text { environment for Effective interaction }\end{array}$ & 16 & $65.0 \%$ & 11 & $27.5 \%$ & 2 & $5.0 \%$ & 1 & $2.5 \%$ & 40 & $100 \%$ \\
\hline $\begin{array}{l}\text { Virtual classroom supports self-discovery } \\
\text { of learning course content }\end{array}$ & 17 & $42.5 \%$ & 21 & $52.5 \%$ & 2 & $5.0 \%$ & 0 & $0 \%$ & 40 & $100 \%$ \\
\hline $\begin{array}{l}\text { Virtual classroom provides time } \\
\text { management facilities for an organized } \\
\text { ongoing activities }\end{array}$ & 17 & $42.5 \%$ & 17 & $42.5 \%$ & 6 & $15.0 \%$ & 0 & $0 \%$ & 40 & $100 \%$ \\
\hline $\begin{array}{l}\text { Virtual classroom provides essential } \\
\text { materials in visible forms }\end{array}$ & 10 & $25.0 \%$ & 15 & $37.5 \%$ & 14 & $15.0 \%$ & 1 & $2.5 \%$ & 40 & $100 \%$ \\
\hline $\begin{array}{l}\text { Virtual classroom provides human } \\
\text { interaction }\end{array}$ & 9 & $40.0 \%$ & 12 & $30.0 \%$ & 16 & $22.5 \%$ & 3 & $7.5 \%$ & 40 & $100 \%$ \\
\hline $\begin{array}{l}\text { Complex information are understood when } \\
\text { offered in several formats }\end{array}$ & 12 & $30.0 \%$ & 18 & $45.0 \%$ & 10 & $25.0 \%$ & 0 & $0 \%$ & 40 & $100 \%$ \\
\hline $\begin{array}{l}\text { Multiple representations of information } \\
\text { delivery in visual forms enables learning }\end{array}$ & 14 & $35.0 \%$ & 15 & $37.5 \%$ & 7 & $17.5 \%$ & 4 & $10 \%$ & 40 & $100 \%$ \\
\hline $\begin{array}{l}\text { The use of emails make my learning } \\
\text { productive }\end{array}$ & 11 & $27.5 \%$ & 21 & $52.5 \%$ & 8 & $20 \%$ & 0 & $0 \%$ & 40 & $100 \%$ \\
\hline I have quick response to my questions & 10 & $25.0 \%$ & 23 & $57.5 \%$ & 5 & $12.5 \%$ & 2 & $5.2 \%$ & 40 & $100 \%$ \\
\hline $\begin{array}{l}\text { There is always internet services to access } \\
\text { my assignment }\end{array}$ & 12 & $30.0 \%$ & 13 & $32.5 \%$ & 10 & $25.0 \%$ & 5 & $12.5 \%$ & 40 & $100 \%$ \\
\hline
\end{tabular}

*AF=Absolute Frequency, $\quad$ RF =Relative Frequency $(\%)$

Results on table 3 show that $65 \%$ of the respondents strongly agree that virtual classroom provides flexible instruction and $27.5 \%$ agree that virtual classroom provides flexible environment for effective interaction while $5.0 \%$ disagree and $2.5 \%$ strongly disagree to this assertion. Similarly, $42.5 \%$ of the respondents strongly agree and $52.5 \%$ agree that virtual classroom supports self-discovery of learning content. Also, $85.1 \%$ of the respondents asserted that virtual classroom provides time management facilities for organized school activities while $15 \%$ disagree to this fact. Equally, the analysis shows that $62.5 \%$ of the respondents agree that use of virtual classroom provides essential materials in visible forms while $37.5 \%$ do not. On provision of human interaction, $70 \%$ of the respondents asserted that interaction is provided when using virtual classroom, while $30 \%$ did not. Also, $75 \%$ of the respondents agreed that complex information are understood when virtual classroom is used while $25 \%$ of the respondents did not. $72.5 \%$ of the respondents also agreed that multiple information developed is provided with virtual classroom while $27.5 \%$ did not. In the same way, $80 \%$ of the respondents asserted that use of e-mail facilities makes instructional processes productive while only $20 \%$ respondents affirmed that use of virtual classroom enabled quick response to questions sent while $17.5 \%$ responded that e-mail does not enable quick response. Lastly, $62.5 \%$ of the respondents asserted that internet services provide access to information for assignment while 37.5 responded otherwise. 


\subsection{Test of Hypothesis}

Hypothesis 1: The use of Virtual classroom does not significantly influence academic performance of Distance Education students in Educational Technology.

The analysis is as seen in table 4

Table 4. T-test Analysis of Use of Virtual Classroom and Academic Performance of Distance Education Students in Educational Technology

\begin{tabular}{lccccccc}
\hline Variable & $\mathrm{N}$ & $\overline{\boldsymbol{X}}$ & $\mathrm{SD}$ & $\mathrm{t}$-value & $\mathrm{t}$-crit & $\mathrm{df}$ & Decision \\
\hline Use Virtual Classroom & 10 & 77.75 & 11.33 & & & & \\
& & & & 7.744 & 1.81 & 9 & Sig. \\
Academic Performance & 10 & 22.25 & 11.33 & & & & \\
\hline \multicolumn{2}{c}{$\mathrm{P}=<.05$ level of significance } & & & & & &
\end{tabular}

The analysis on table 4 indicates a significant difference on use of Virtual classroom on academic performance of Educational Technology students in Distance Education. The t-test value of 7.744 was seen to be highly significant at .05 alpha level. The hypothesis is therefore rejected, this means that use of virtual classroom significantly influence academic performance of Educational Technology students in the Distance Education center, Enugu state- Nigeria.

\section{Discussion of Findings}

Results of the analysis revealed that live audio-video support, whiteboard, multi-level feedback mechanism, live tech support, synchronous learning were available for virtual classroom instruction. This finding was supported by Hall (2012) who opined that for the virtual classroom to be successful, these elements must be available. This implies that virtual classroom instruction is available in the National Open University, Enugu State.

However, it was further discovered that although virtual classroom instruction is available, live audio-video support, whiteboard, multi-level feedback mechanism, live tech support, synchronous learning were not often used in instruction. This study is in line with the work of Mallareddy (2013) whose study revealed that there was lack of tools and technology and also lack of interaction with the facilities and the learners.

The study also revealed that virtual classroom provide flexible environment for effective interaction, support self-discovery of learning content, provides time management facilities for organized activities, provides essential materials in visible format and provides human interaction. This is also supported by Gedera, (2014) who asserted that most of the students preferred to have virtual classroom activities because of the presence of cues and human interaction.

The study also showed a significant influence of use of virtual classroom on academic performance of Distance Educational Technology students. The reason for this result is that virtual classroom promotes flexible learning and access to instructional facilities and information. It promotes independent and autonomous learning as well as discovery of knowledge and skills. This is supported by the submission of Perumalla et al (2011) who opined that use of virtual classroom ensures effectiveness of instruction that enhance students' performance. The study is also supported by the work of Gedera (2014) and Mallareddy (2015) who showed that use of virtual classroom developed better understanding of students experiences during learning and also it removes barriers of time and space, overcome the unavailability of teachers, sessions and can be quick to organize.

The implication of this study is that use of virtual classroom if extended to Distance education programs in Nigeria can enhance quick access to instruction, knowledge and skills developments, development of competencies and academic performance of students especially in Educational Technology courses.

\section{Conclusion}

This study concludes that virtual classroom promotes instructional strategies like collaboration, independent, autonomous, synchronous and asynchronous instructional strategies that expose Distance Education students to access information, knowledge and skills. These attributes are important predictors of Teaching, learning and academic performance. 


\section{Recommendations}

The following recommendations are rendered to facilitate effective use of virtual classroom in teaching and learning of Distance Education students.

1. Virtual classroom should be developed by Distance Education Universities and Institutes, government, heads of Institutions and non-governmental organizations to provide facilities for distance education as a sure way of reaching out to the citizenry for knowledge, skills and competencies development.

2. Government and Education bodies should ensure constant power generation to sustain easy access and contact to virtual classrooms.

3. Teachers should be trained on the development and use of virtual classrooms by organized bodies and institutions.

4. Students should also be trained on the use of virtual classroom for easy access to education and learning capabilities.

\section{References}

Beyth-Marom, R., Chajut, E., Roccas, S., \& Sagiv, L. (2003). Internet-assisted versus traditional distance learning environments: factors affecting students' preferences. Compiters \& Education, 41, 65-76. https://doi.org/10.1016/S0360-1315(03)00026-5

Cinar, M., \& Torenli, N. (2010). Redesign online courses with students' expectations: a case study with a new infrastructure. Social and Behavioural Science, 9, 2013-2016. https://doi.org/10.1016/j.sbspro.2010.12.438

Falloon, G. (2012). Inside the virtual classroom: Student perception on affordance and limitation. Journal of Open, Flexible and Distance Learning, 16(1), 108-126

Gedera, D.P.S (2014). Students' experience of learning in a virtual classroom. International Journal of Education and Development using Information and Communication Technology (IJEDICT), 10(4), 93-101.

Hall, C. (2012). Teaching and learning in a virtual environment. Interface; the Journal of Education, Community, and values, 12, 1-4.

Isik, A. H., Karakis, R., \& Guler, I. (2010). Postgraduate students' attitudes toward distance learning (the case study of Gazi University). Social and Behavioural Science, 9, 218-222. https://doi.org/10.1016/j.sbspro.2010.12.139

Karakoyun, F., \& Karak, M. T. (2009). The opinions of academicians regarding distance learning: a sample of Dicle University. Social and Behavioural Science, 1, 1172-1176. https://doi.org/10.1016/j.sbspro.2009.01.211

Mallareddy, A. (2013). Advantages and limitations of virtual classroom in telugu language teaching. Journal of Humanities and Social Science (IOSR-JHSS), 15(6), 54-56. https://doi.org/10.9790/0837-1565456

Perumalla, C., Mak, J., Kee, N., \& Maththews, S. (2011). Integrating web applications to provide an effective distance online learning environment for students. Computer Science, 3, 770-784. https://doi.org/10.1016/j.procs.2010.12.127 